\title{
INFLUENCE OF OXIDATIVE STRESS AND INFLAMMATION ON THE DEVELOPMENT OF ISCHEMIC HEART DISEASE IN PATIENTS WITH TYPE 2 DIABETES MELLITUS
}

\author{
Lilic J. L. , Djindjic B. Dj. ${ }^{1,2}$, Kostic T.K. ${ }^{2}$, Jovanovic A. J. ${ }^{3}$, Stanojevic D. S. ${ }^{2}$
}

\begin{abstract}
Aim. Ischemic heart disease (IHD) is the result of endothelial dysfunction, which is associated with inflammation, increased oxidative stress and hyperglycemia. The aim of our study was to examine the aetiology, importance and intensity of inflammation and oxidative stress in IHD development in patients with diabetes mellitus
\end{abstract} (DM) type 2

Material and methods. We included 60 male patients with IHD of whom 30 with diabetes type 2. Control group comprised of 12 healthy participants. We analyzed the lipid status, quality of glycemic control (daily glycemia profile - MBG and $\mathrm{HbA}_{1 \mathrm{c}}$ ), lipid peroxidation (malondialdehyde-MDA) and inflammation: high sensitivity $C$ reactive protein (hsCRP), intercellular and vascular adhesion molecule-1 (ICAM-1, VCAM-1).

Results. Patients with DM type 2 and IHD were obese with higher levels of $\mathrm{HbA}_{1 \mathrm{c}}$ and $\mathrm{MBG}$ compared to other two groups. Systolic and diastolic blood pressure, triglycerides, total and LDL cholesterol were significantly higher and $\mathrm{HDL}$ was lower in all patients with IHD compared to the control group. CRP levels, ICAM-1, VCAM-1 and MDA were significantly higher in the groups with IHD compared to the control. MDA and VCAM-1 were higher in patients with IHD and type $2 \mathrm{DM}$ than in patients with IHD. There was a significant positive correlation between hsCRP and LDL cholesterol in patients with IHD, regardless of the presence of DM. Significant positive correlation between VCAM-1 and $\mathrm{HbA} 1 \mathrm{c}$ values, and between ICAM-1 and hsCRP were shown only in patients with IHD and DM type 2 .

Conclusion. Inflammation, increased oxidative stress, lipid and metabolic disorders showed significant correlation and have an important pathogenic role in the development of IHD, particularly in patients with DM type 2. Increased levels of hsCRP, VCAM-1 and products of lipid peroxidation are characteristic markers of endothelial inflammation and indicators of the presence of atherosclerotic plaque in patients with DM type 2.

Russ J Cardiol 2016, 4 (132), Engl.: 148-152

http://dx.doi.org/10.15829/1560-4071-2016-4-eng-148-152

Key words: diabetes mellitus, oxidative stress, inflammation, adhesion molecules.

${ }^{1}$ Medical faculty, University of Nis, Nis; ${ }^{2}$ Clinic for cardiovascular diseases, Clinical Center Nis, Nis; ${ }^{3}$ Clinic for thoracic surgery, Clinical Center Nis, Nis, Serbia.

Corresponding author. Dragana Stanojevic, MD, MSc, internist in ICU at Clinical Centre Nis Address Bulevar dr Zorana Đinđića 48, 18000, Niš, Serbia, Mail: draganastanojevic1@gmail.com Phone: +381643068447.

BMI - body mass index, CAM - cellular adhesive molecules, DM - diabetes mellitus, HbA1c - glycosylated haemoglobin, HDL - high density lipoprotein, hsCRP - high sensitivity $C$ reactive protein, ICAM-1 - intercellular adhesion molecule-1, IHD - Ischemic heart disease, LDL - low density lipoprotein, MBG - daily glycemia profile, MDA - malondialdehyde, SAP - stable angina pectoris, TC total cholesterol, UKPDS study - The United Kingdom Prospective Diabetes Study VCAM-1 - vascular adhesion molecule-1.

Received December 22, 2015.

Revision received January 29, 2016

Accepted February 05, 2016

\section{САХАРНЫЙ ВЛИЯНИЕ ОКСИДАТИВНОГО СТРЕССА И ВОСПАЛЕНИЯ В РАЗВИТИИ ИШЕМИЧЕСКОЙ БОЛЕЗНИ СЕРДЦА У БОЛЬНЫХ САХАРНЫМ ДИАБЕТОМ 2 ТИПА}

Lilic J. L. ${ }^{1}$, Djindjic B. Dj. ${ }^{1,2}$, Kostic T. K. ${ }^{2}$, Jovanovic A. J. ${ }^{3}$, Stanojevic D. S. ${ }^{2}$

Цель. Ишемическая болезнь сердца (ИБС) является следствием эндотелиальной дисфункции, которая связана с воспалением, повышением окислительного стресса и гипергликемии. Целью нашего исследования явилось изучение этиологии, значения и интенсивности воспаления и оксидативного стресса в развитии ИБС у больных сахарным диабетом (СД) 2 типа.

Материал и методы. Мы включили 60 пациентов мужского пола с ИБС, 30 из которых с СД 2 типа. Группу контроля составили 12 здоровых участников. Мы проанализировали липидный статус, качество гликемического контроля (ежедневный гликемический профиль - MBG и $\mathrm{HbA}_{10}$ ), перекисного окисления липидов (малонового диальдегида (MDA)) и воспаления: высокочувствительного C реактивного белка (hsCRP), межклеточные и сосудистые молекулы адгезии-1 (ICAM-1, VCAM-1)

Результаты. Пациенты с СД 2-го типа и ИБС, страдающие ожирением, имели более высокие уровни MBG и $\mathrm{HbA}_{1}$, по сравнению с двумя другими группами Систолическое и диастолическое артериальное давление, уровень триглицеридов, общего холестерина и холестерина лПнП были достоверно выше а уровень ЛПВП был ниже у всех больных с ИБС, по сравнению с контрольной группой. Уровни hsCRP, ICAM-1, VCAM-1 и мда были достоверно выше в группах с ИБС по сравнению с контролем. MDA и VCAM-1 были выше у пациентов с ИБС и СД 2-го типа, чем у пациентов с ИБС. Существует значительная поло- жительная корреляция между hsCRP и холестерином ЛПНП у пациентов с ИБС, независимо от наличия СД. Значимая положительная корреляция между VCAM-1 и значениями $\mathrm{HbA}_{1 \mathrm{c}}$, и между ICAM-1 и hsCRP было показано только у пациентов с ИБС и СД 2-го типа.

Заключение. Воспаление, увеличивается окислительный стресс, липидный и метаболических нарушений показал значимую корреляцию и играют важную патогенетическую роль в развитии ИБС, особенно у пациентов с СД 2-го типа. Повышенный уровень hsCRP, VCAM-1 и продуктов перекисного окисления липидов являются характерными маркерами эндотелиального воспаления и наличия атеросклеротической бляшки у пациентов с СД 2-го типа.

Российский кардиологический журнал 2016, 4 (132), Англ.: 148-152 http://dx.doi.org/10.15829/1560-4071-2016-4-eng-148-152

Ключевые слова: сахарный диабет, окислительный стресс, воспаление, молекулы адгезии.

${ }^{1}$ Medical faculty, University of Nis, Nis; ${ }^{2}$ Clinic for cardiovascular diseases, Clinical Center Nis, Nis; ${ }^{3}$ Clinic for thoracic surgery, Clinical Center Nis, Nis, Serbia. 
The latest studies of atherosclerosis indicate that inflammatory response within the arterial wall is a significant pathogenic factor. The findings show that inflammation contributes to the occurrence of acute cardiovascular disease and it is also the key of initiation and progression of atherosclerosis. However, the characteristics of the inflammatory process in diabetes mellitus (DM) type 2 are still not completely elucidated considering the fact that this disease is characterized by the numerous pro-inflammatory, pro-oxidative and procoagulant risk factors. It is considered that hypercholesterolemia, hypertension, hyperglycaemia, obesity, hyperinsulinemia, decreasing concentration of estrogens and smoking are the main pro-inflammatory triggers. Initiation of this chronic inflammatory process starts with monocytes adhesion on endothelial surface due to adhesive molecules expressed on the endothelium [1]. Cellular adhesive molecules (CAM), primarily intracellular adhesive molecule-1 (ICAM-1) and vascular cellular adhesive molecule-1 (VCAM-1) are rarely manifested on endothelium in resting phase, and they are activated in the presence of inflammation and could be the indicators of endothelial activation or markers of an early stage of atherosclerosis [2]. This process can be caused by cascade of inflammatory reactions, which include monocytes, macrophages, T lymphocytes and smooth muscular cells. These cells and endothelium produce adhesive molecules, cytokines, growth factors, metalloproteinases which cause accelerated atherogenesis [1,2].

The increase in CAM in conditions of hyperglycemia leads to accelerated and diffuse atherosclerosis through the increased intensity of oxidative stress, also. It is shown that in diabetes there is a hyper oxidative stress and a reduction of antioxidant protection [3]. The increase of oxidative modification of small and dense LDL particles, which are characteristic of diabetic dyslipidemia, is a key factor in the growth of the lipid core of atheromatous plaque. This process is facilitated not only by increased oxidative stress in the blood vessel wall, but also by reducing antioxidant protection and proinflammatory state. Therefore, in patients with type $2 \mathrm{DM}$ the processes of oxidative modification of proteins and lipids peroxidation are especially enhanced. Oxidative stress affects the expression of many genes in endothelial cells, causing endothelial disfunction [4].

The aim of this study was to examine the connection between inflammation and pathogenic importance and intensity of oxidative stress in the development of ischemic heart disease in patients with diabetes mellitus type 2 .

\section{Material and methods}

This study was conducted with respect to Good Clinical Practice guidelines and the Declaration of Helsinki. Local Ethic Committee approved the study protocol, and all participants before enrolment in the study signed informed consent.
In a prospective clinical cross-sectional study, 60 male patients with stable ischemic heart disease (IHD), ambulatory treated and 12 healthy male subjects were analyzed. The study did not include patients with acute and chronic inflammatory diseases, liver disease, microalbuminuria and those who had anti-inflammatory medications, vitamins and antioxidants in their treatment. In all patients, a detailed history was taken, complete medical records were obtained, blood pressure measured and body mass index (BMI) was calculated. All subjects were divided into three groups:

- group I - 30 patients with type 2 diabetes mellitus and ischemic heart disease;

- group II -30 patients with ischemic heart disease without diagnosed diabetes mellitus type 2;

- group III - 12 healthy subjects in whom the examination excluded ischemic heart disease and diabetes mellitus.

Ischemic heart disease implied presence of stable angina pectoris (SAP), which is diagnosed based on the appearance of chest pain with characteristic quality provoked by the physical effort or emotional stress and which stops after rest and/or taking nitroglycerin lingualettes [5]. All patients had a positive stress test performed on ergobicycle with the increasing load on every 3 minutes for $25 \mathrm{~W}$ until the indication for stopping the test emerged. Patients with angina at rest were excluded from the study.

The diagnosis of diabetes mellitus type 2 has been confirmed from the medical records.

In all groups, blood samples were taken from the cubital vein in the morning, before breakfast and before morning therapy. We performed a biochemical determination by plasma glucose analyzer "AXON" (Bayer Company). Glycaemia were expressed in $\mathrm{mmol} / \mathrm{L}$.

We took five capillary blood samples: during the morning, noon, evening (fasting), and postprandial, 2 hours after breakfast and lunch. The mean value of the daily glucose profile (MBG) was obtained by calculating the average value of all five measurements, and expressed in $\mathrm{mmol} / \mathrm{L}$.

Glycosylated haemoglobin (HbAlc), high sensitivity C-reactive protein (hsCRP), total serum cholesterol (TC), triglycerides, HDL and LDL cholesterol values were measured on the machine Dimension Xpand using Dade Behring reagents.

Lipid peroxidation was determined by measuring malondialdehyde (MDA) levels, as one of the final products of lipid peroxidation by the method of Andreev et al. MDA at high temperature under acidic conditions with the addition of thiobarbituric acid (TBA) and ferrous ion creates pink coloration. Absorption chromogen was measured at $532 \mathrm{~nm}$. MDA concentrations were expressed in $\mu \mathrm{mol} / \mathrm{L}$.

Adhesion molecules (ICAM-1 and VCAM-1) were measured by ELISA method using commercial test by 
Table 1

Clinical and laboratory characteristics of the included groups

\begin{tabular}{|l|l|l|l|}
\hline Parameters & IHD+DM type 2 & IHD & Control \\
\hline Number & 30 & 30 & 12 \\
\hline Years & $54,5 \pm 5$ & $56 \pm 6$ & $52 \pm 6$ \\
\hline sysTA(mmHg) & $146 \pm 12^{(a, b)}$ & $130 \pm 16^{(a)}$ & $104 \pm 5$ \\
\hline diaTA(mmHg) & $93 \pm 7^{(a)}$ & $88 \pm 12^{(a)}$ & $73 \pm 6$ \\
\hline BMI(kg/m $\left.{ }^{2}\right)$ & $30,5 \pm 3,6^{(a, b)}$ & $25,3 \pm 2,1$ & $24 \pm 1$ \\
\hline MBG(mmol/l) & $12,1 \pm 2,9^{(a, b)}$ & $6,4 \pm 1$ & $6,1 \pm 1$ \\
\hline HbA $(\%)$ & $8,9 \pm 1^{(a, b)}$ & $5,2 \pm 1$ & $5 \pm 1$ \\
\hline Triglycerides (mmol/l) & $3,3 \pm 1,1^{(a)}$ & $2,79 \pm 0,7^{(a)}$ & $1,73 \pm 0,36$ \\
\hline Cholesterol (mmol/l) & $8,5 \pm 1,56^{(a, b)}$ & $6,3 \pm 1,6^{(a)}$ & $5,2 \pm 1,1$ \\
\hline HDL Cholesterol (mmol/l) & $0,95 \pm 0,26^{(a)}$ & $1,1 \pm 0,5^{(a)}$ & $1,35 \pm 0,37$ \\
\hline LDL Cholesterol (mmol/l) & $6,1 \pm 1,56^{(a, b)}$ & $4,2 \pm 1,8^{(a)}$ & $3,3 \pm 1,1$ \\
\hline Family history of IHD n(\%) & $16(53)^{(b)}$ & $26(86)$ & $3(25)^{(b)}$ \\
\hline Smoking n (\%) & $14(46)^{(b)}$ & $29(96)$ & $4(33)^{(b)}$ \\
\hline Therapy (\%) & & & \\
\hline Nitrates & $48(80)$ & $34(56)$ & - \\
\hline Beta blockers & $34(56)$ & $26(44)$ & $2(13)$ \\
\hline Ca antagonist & $10(16)$ & $22(36)$ & $1(7)$ \\
\hline ACE inhibitors & $26(44)$ & $24(40)$ & $3(27)$ \\
\hline Statins & $10(16)$ & $14(24)$ & - \\
\hline Aspirin & $43(72)$ & $26(44)$ & - \\
\hline
\end{tabular}

Annotation: ANOVA test and post hoc Tukey HSD analysis or Chi2 test: ${ }^{a}-p<0,05$ vs. healthy subjects, ${ }^{\text {b }}-p<0,05$ vs. group with IHD.

Abbreviations: IHD - ischemic heart disease, DM type 2 - diabetes melitus type 2

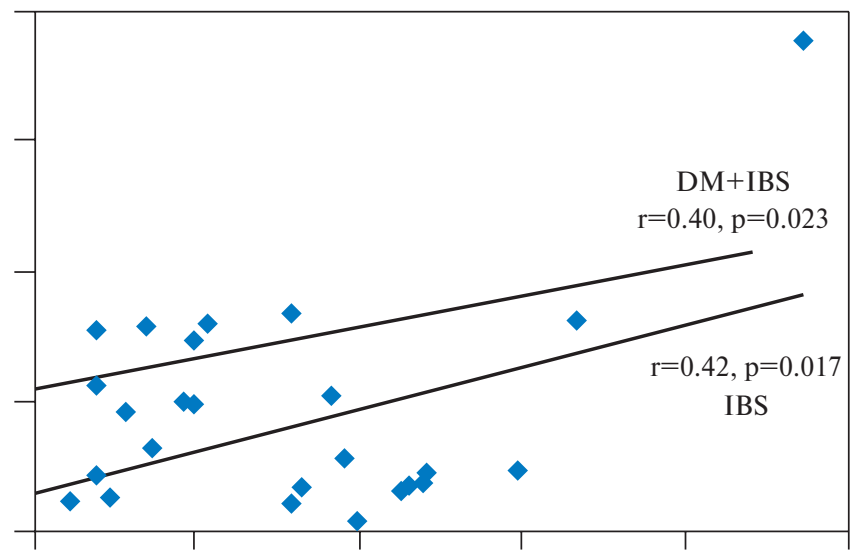

Figure1. Correlation between CRP levels and the protective HDL cholesterol in patients with IHD.

Beckman Coulter Company on Bio-Systems propeller Rider. The results were expressed in ng/mL. For VCAM-1 measurement range was $0-25 \mathrm{ng} / \mathrm{mL}$ and sensitivity was $0.74 \mathrm{ng} / \mathrm{mL}$. Accordingly, for ICAM-1 measurement range was $0-16 \mathrm{ng} / \mathrm{mL}$ with sensitivity of $0.1 \mathrm{ng} / \mathrm{mL}$.

Statistical analysis were performed in Excel 7.0 and SPSS 11.0 in Windows XP environment using standard descriptive methods (mean, standard deviation, percentage) and appropriate analytical tests depending on the type and size of the sample (Student's t test, chi-square
Table 2

The oxidative and inflammatory parameters in groups

\begin{tabular}{|l|l|l|l|}
\hline Parameters & IHD+DM type 2 & IHD & Control \\
\hline MDA $(\mu \mathrm{mol} / \mathrm{l})$ & $16,47 \pm 5,84^{(\mathrm{a}, \mathrm{b})}$ & $13,42 \pm 4,01^{(\mathrm{a})}$ & $8,24 \pm 2,8$ \\
\hline hsCRP $(\mathrm{mg} / \mathrm{l})$ & $4,2 \pm 2,5^{(\mathrm{a})}$ & $4,1 \pm 2,1^{(\mathrm{a})}$ & $3,2 \pm 1,8$ \\
\hline ICAM-1 $(\mathrm{ng} / \mathrm{ml})$ & $\left.707,4 \pm 145,1^{(} \mathrm{a}\right)$ & $699,2 \pm 125,6^{(\mathrm{a})}$ & $543,4 \pm 86,6$ \\
\hline VCAM-1 $(\mathrm{ng} / \mathrm{ml})$ & $971 \pm 172,2^{(\mathrm{a}, \mathrm{b})}$ & $823,4 \pm 97,6^{(\mathrm{a})}$ & $784,9 \pm 99,2$ \\
\hline
\end{tabular}

Annotation: ANOVA test and post hoc Tukey HSD analysis or Chi2 test: ${ }^{a}-p<0,05$ vs. healthy subjects, ${ }^{\text {b }}-p<0,05$ vs. group with IHD.

Abbreviations: IHD - ischemic heart disease, DM type 2-diabetes melitus type 2.

test, ANOVA test and post hoc analysis Tukey HSD test, Pearson's correlation coefficient).

\section{Results}

The main characteristics of examined groups are shown in Table 1. Patients with DM type 2 and IHD had significantly higher body mass index (BMI) compared to the patients with IHD without DM and with healthy examinees $(\mathrm{p}<0,05) . \mathrm{HbA}_{1 \mathrm{c}}$ and $\mathrm{MBG}$ levels were significantly higher in patients with DM type 2 and IHD compared to other two groups $(\mathrm{p}<0,05)$. Other characteristics of the groups: systolic and diastolic blood pressure, triglyceride and LDL cholesterol values were significantly higher, while HDL was significantly lower in the groups of patients with IHD compared to the control group $(\mathrm{p}<0,05)$ (Table 1$)$.

Inflammatory markers (hsCRP, ICAM-1, and VCAM-1) and indicator of the intensity of oxidative stress (MDA) were significantly higher in the groups of patients with IHD, regardless of the presence of DM type 2, compared to the group of healthy examinees $(p<0,05)$. MDA and VCAM-1 values were significantly higher in patients with IHD and DM type 2 compared to the patients with IHD without DM $(\mathrm{p}<0,05)$ (Table 2).

Inflammatory and oxidative stress markers, together with lipid and metabolic risk factors, showed positive correlation with hsCRP and LDL cholesterol values, in the groups of patients with IHD regardless of the presence of DM $(p<0,05)$ (Figure 1). Significant positive correlation of VCAM- 1 and HbA1c values was found, and the ICAM-1 values correlated with the concentration of hsCRP only in the group of patients with IHD and DM type $2(p<0,05)$ (Figure 2 and 3). Similar correlations were not found in the group of healthy examinees.

\section{Discussion}

Atherosclerosis is a disease with a great number of risk factors, which accelerate atherogenesis with its cumulative activities. It is considered that in the core of this process, is endothelial dysfunction connected with the inflammation and increased intensity of oxidative stress in the blood vessel wall [1].

Disturbed composition and concentration of lipid in diabetes mellitus type 2 is called diabetic dyslipidemia, and 
has all characteristic of dyslipidemia in metabolic syndrome, since both are characterized by insulin resistance. Mentioned disorders are reflected in low values of HDL cholesterol, increase of concentration of total cholesterol due to high LDL cholesterol, presence of postprandial lipemia and hypertriglyceridemia [6]. Our findings in patients with IHD are in accordance with the mentioned study.

Modern understanding of the pathogenesis of atherosclerosis includes inflammatory component in its development. Today, it is considered that this inflammatory process of arterial wall is a consequence of different stimuli. Increased levels of adhesion molecules ICAM-1 and VCAM-1, and hsCRP in patients with IHD are reported by many authors [7]. Accordingly the similar results are obtained in our study. It is known that the concentration of adhesion molecules varies, depending on the stage and the presentation of coronary atherosclerosis. VCAM-1 levels are good markers of activity of the atherosclerotic process, and they are the highest in acute coronary syndromes, while the lowest values are registered in patients with stable angina pectoris. Levels of ICAM-1 molecules are good markers of the presence of developed atherosclerotic lesions and they do not vary significantly compared to the clinical manifestation of coronary atherosclerosis. Usually, both adhesion molecules have significantly higher concentrations in patients with IHD compared to the healthy population [8]. Our findings are in line with those observations (Table 2).

Mechanism of increase in cellular adhesion molecules (CAM) levels can be attributed to hyperglycemia, hyperinsulinemia, oxidative stress, and inflammation and insulin resistance [9]. Therefore, the level of CAM cannot be observed only as a marker of activation of endothelial cells, accelerated adherence and activation of leukocytes, but also as a marker of increased oxidative stress, inflammation and metabolic disorders. This is in accordance with significantly higher VCAM-1 values in patients with IHD and DM type 2, compared to the patients with IHD without DM (Table 2) and we demonstrated positive correlation of VCAM-1 with $\mathrm{HbAlc}$ values (Figure 2). All this indicates the importance of metabolic disorders in the development of endothelial dysfunction and accelerated atherogenesis, which is pointed out by other authors [10]. Correlation is found between ICAM-1 and hsCRP concentrations (Figure 3). This connects the presence of developed atherosclerotic lesion with inflammatory disorders in patients with DM type 2 [11].

Lipid peroxidation level measured by the MDA concentration was the highest in patients with DM type 2 and IHD. It was also higher in the group of patients with IHD regardless of the presence of diabetes mellitus compared to the control group (Table 2). Diabetic patients have increased lipid peroxidation which is associated with hyperglycemia and increased risk for IHD. Inflammation,

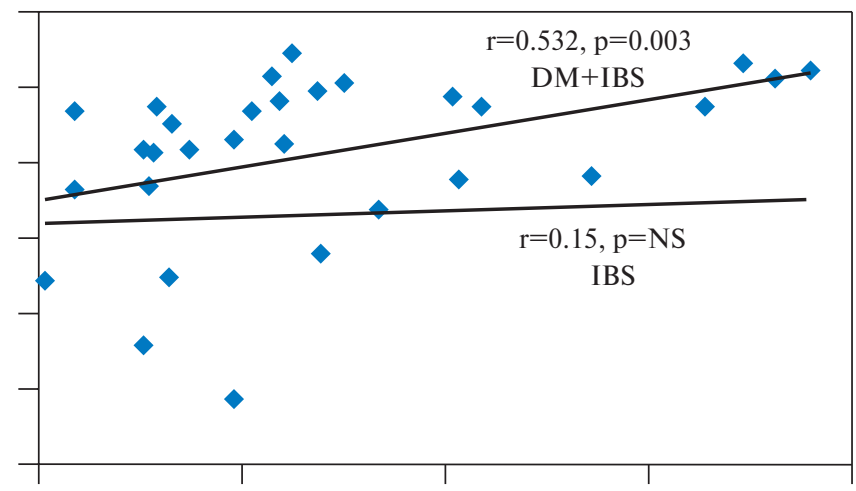

Figure 2. Positive correlation between VCAM-1 and HbA1c in patients with IHD and DM type 2.

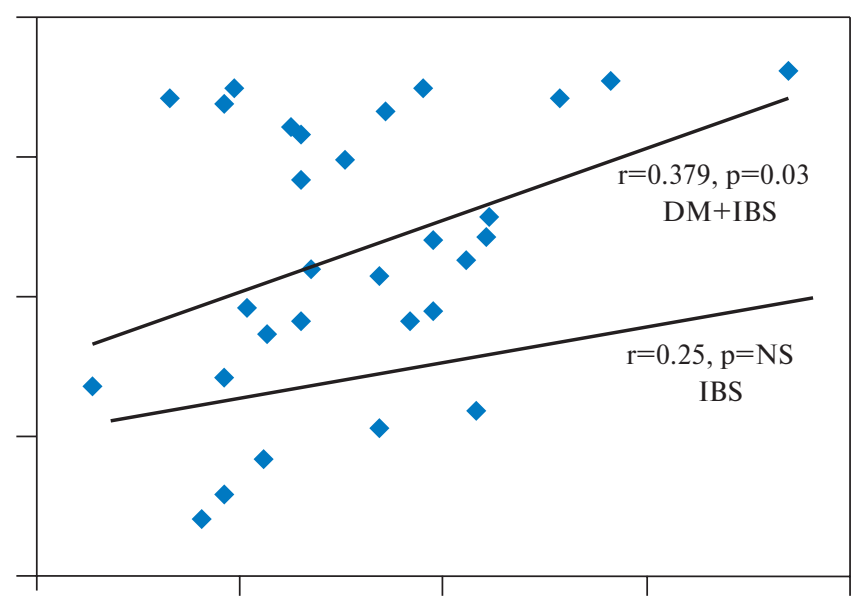

Figure 3. Correlation between ICAM-1 and CRP in the examined groups of patients.

oxidation of LDL particles and increase in CRP are caused by the increase of LDL cholesterol and decrease of HDL with the fall of paraoxonase activity due to the inhibition of paraoxonase 1 by the lipid peroxide [12, 13]. Having in mind the importance of this anti-inflammatory enzyme for the production of CRP it is possible to explain the close connection between diabetes, oxidative stress and inflammation in development of endothelial dysfunction and pathogenesis of atherosclerosis [14]. This was shown in our study by connecting LDL cholesterol and hsCRP concentrations in all patients with IHD.

Direct connection of hyperlipidemia with increased values of hsCRP and CAM is the evidence of noteworthy relation between lipid disorders, endothelial dysfunction and inflammation. The importance of lipid disorders in patients with DM type 2 is exceptionally demonstrated by the fact that decreased HDL and increased LDL have stronger prognostic significance for the occurrence of cardiovascular diseases than the value of hyperglycemia in the UKPDS and other studies [15].

\section{Conclusion}

Inflammation, increased level of oxidative stress, lipid and metabolic disorders have significant connection and 
have an important pathogenic role in the development of ischemic heart disease, particularly in patients with diabetes mellitus type 2. Increased levels of hsCRP, VCAM-1 and products of lipid peroxidation are markers of endothelial inflammation and indicators of the presence of

\section{References}

1. Mangge $H$, Almer $G$, Truschnig-Wilders $M$, et al. Inflammation, adiponectin, obesity and cardiovascular risk. Curr Med Chem 2010; 17(36):4511-20.

2. Tousoulis $\mathrm{D}$, Antoniades $\mathrm{C}$, Stefanadis $\mathrm{C}$. Assessing inflammatory status in cardiovascular disease. Heart 2007; 93(8):1001-7.

3. Ferderbar S, Pereira EC, Apolinário E, et al. Cholesterol oxides as biomarkers of oxidative stress in type 1 and type 2 diabetes mellitus. Diabetes Metab Res Rev 2007; 23(1):35-42.

4. Tabit CE, Chung WB, Hamburg NM, et al. Endothelial dysfunction in diabetes mellitus: molecular mechanisms and clinical implications. Rev Endocr Metab Disord 2010; 11(1):61-74.

5. Fox K, Garcia MA, Ardissino D, et al. The Task Force on the management of stable angina pectoris of the European Society of Cardiology. Guidelines on the management of stable angina pectoris: executive summary. Eur Heart J 2006; 27:1341-81.

6. Zoungas $\mathrm{S}$, de Galan BE, Ninomiya $T$, et al. Combined effects of routine blood pressure lowering and intensive glucose control on macrovascular and microvascular outcomes in patients with type 2 diabetes: New results from the ADVANCE trial. Diabetes Care 2009; 32(11):2068-74

7. Suzuki T, Katz R, Jenny NS, et al. Metabolic syndrome, inflammation, and incident heart failure in the elderly: the cardiovascular health study. Circ Heart Fail 2008;1(4):242-8.

8. Damnjanović $G$, Jelić M, Dindić B, llić S. Serum concentration of soluble adhesive molecules in patients with different forms of coronary artery disease. [Article in Serbian] Vojnosanit Pregl 2009; 66(4):265-70. atherosclerotic plaque in patients with DM type 2. Since these patients have increased risk for cardiovascular diseases, continuous prevention and aggressive treatment of these disorders is required in order to prevent the formation of severe clinical manifestations of atherosclerotic disease.
9. Zanni MV, Stanley TL, Makimura $\mathrm{H}$, et al. Effects of TNF-alpha antagonism on E-selectin in obese subjects with metabolic dysregulation. Clin Endocrinol (Oxf) 2010;73(1):48-54.

10. el-Mesallamy $\mathrm{H}$, Suwailem S, Hamdy N. Evaluation of C-reactive protein, endothelin-1, adhesion molecule(s), and lipids as inflammatory markers in type 2 diabetes mellitus patients. Mediators Inflamm 2007; 2007:73635.

11. Djindjić B, Ranković G, Živić M, et al. Gender difference in hipolipemic and antiinflammatory effects of statins in diabetics with coronary artery disease. [Article in Serbian]. Vojnosanit Pregl 2009; 66(12):966-72.

12. Mackness B, Quarck R, Verreth W, et al. Human Paraoxonase-1 Overexpression Inhibits Atherosclerosis in a Mouse Model of Metabolic Syndrome. Arterioscler Thromb Vasc Biol 2006; 26:1545-50.

13. Mackness $B$, Hine D, McElduff $P$, et al. High C-reactive protein and low paraoxonase 1 in diabetes as risk factors for coronary heart disease. Atherosclerosis 2006; 186(2):396401

14. Dullaart RP, de Vries R, Sluiter WJ, et al. High plasma C-reactive protein (CRP) is related to low paraoxonase-I (PON-I) activity independently of high leptin and low adiponectin in type 2 diabetes mellitus. Clin Endocrinol (Oxf) 2009; 70(2):221-6.

15. Berry C, Tardif JC, Bourassa MG. Coronary heart disease in patients with diabetes: part I: recent advances in prevention and noninvasive management. J Am Coll Cardiol 2007;49(6):631-42. 